\title{
90TH ANNUAL
}

\section{ACADEMY AWARDS OF MERIT}

FOR ACHIEVEMENTS DURING 2017

\section{INDEX}

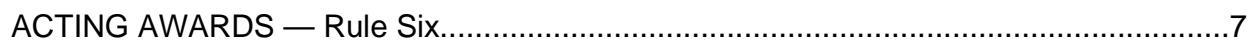

ANIMATED FEATURE FILM AWARD — Rule Seven...........................................

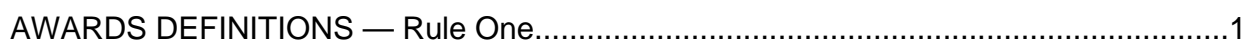

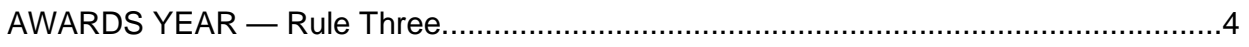

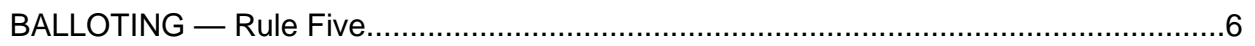

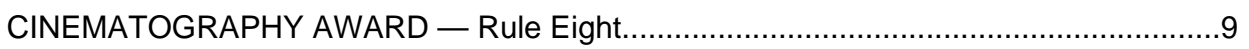

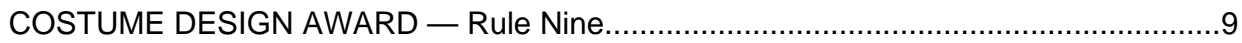

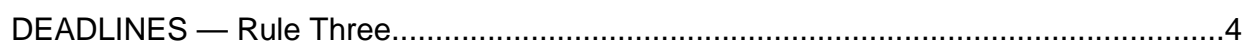

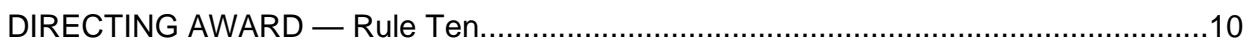

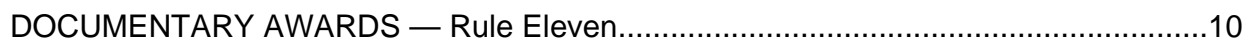

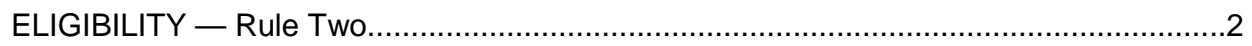

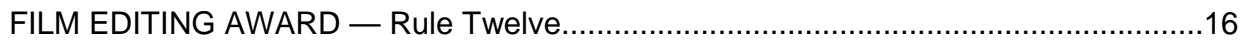

FOREIGN LANGUAGE FILM AWARD — Rule Thirteen ...............................................16

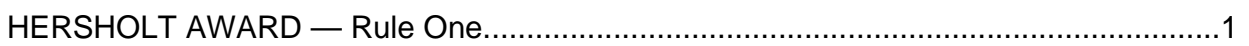

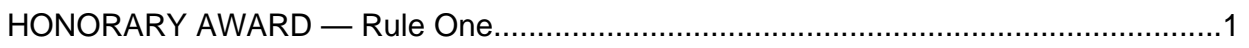

MAKEUP AND HAIRSTYLING AWARD — Rule Fourteen........................................19

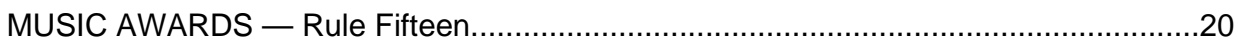

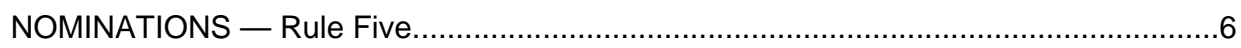

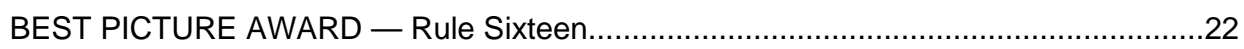

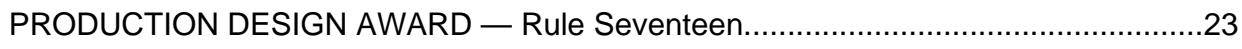

SCIENTIFIC AND TECHNICAL AWARDS — Rule Eighteen..........................................24

SCIENTIFIC AND TECHNICAL SPECIAL AWARDS - Rule Twenty-six....................... 33

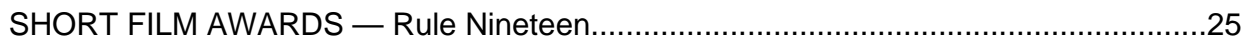

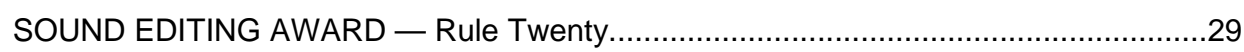

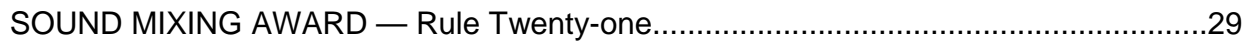

SPECIAL ACHIEVEMENT AWARD — Rule Twenty-five.............................................33

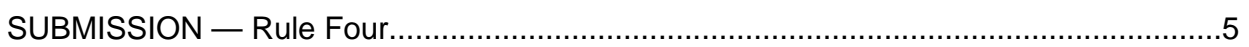

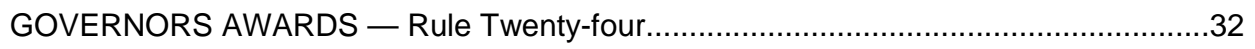

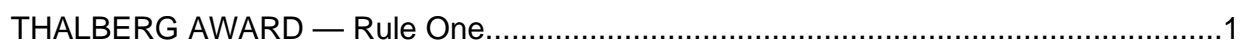

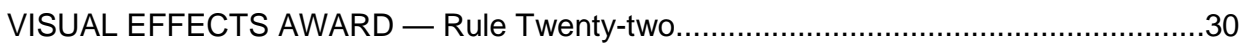

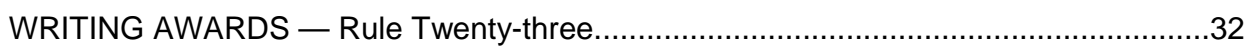




\section{TH ACADEMY AWARDS OF MERIT}

\section{RULE ONE \\ AWARDS DEFINITIONS}

1. Academy Awards of Merit shall be given annually to honor outstanding artistic and scientific achievements in theatrically released feature-length motion pictures, and to honor other achievements as provided for in these rules and approved by the Board of Governors.

2. Awards shall be conferred at an annual Awards ceremony.

3. Awards of Merit in the form of the gold statuette trophy of the Academy (Oscar) shall be conferred annually for the following achievements:

ACTING:

ANIMATED FEATURE FILM:

CINEMATOGRAPHY:

COSTUME DESIGN:

DIRECTING:

DOCUMENTARY:

FILM EDITING:

FOREIGN LANGUAGE FILM:

MAKEUP AND HAIRSTYLING:

MUSIC:

BEST PICTURE:

PRODUCTION DESIGN:

SHORT FILM:
Performance by an actor in a leading role. Performance by an actor in a supporting role. Performance by an actress in a leading role. Performance by an actress in a supporting role.

Best animated feature film of the year.*

Achievement in cinematography.

Achievement in costume design.

Achievement in directing.

For each of two classifications:

a. Best documentary feature.

b. Best documentary short subject.

Achievement in film editing.

Best foreign language film of the year.

Achievement in makeup and hairstyling.

For achievements in music written for motion pictures:

a. Original score.*

b. Original song.*

c. Original musical.*

Best motion picture of the year.

Achievement in production design. (The Academy statuette shall be given also for the set decoration on the picture that wins the Production Design award. ${ }^{\star *}$ )

For each of two classifications:

a. Best animated short film.

b. Best live action short film. 
SOUND EDITING:

SOUND MIXING:

VISUAL EFFECTS:

WRITING:
Achievement in sound editing.

Achievement in sound mixing.

Achievement in visual effects.

For each of two classifications:

a. Adapted screenplay.

b. Original screenplay.

* May not be given every year. See special rules for this category for conditions of presentation.

** See special rules for this category for conditions of presentation for animated feature films.

4. The following Governors Awards shall be given at such times as in the judgment of the Board of Governors there are deserving recipients, but are not necessarily given each year:

a. IRVING G. THALBERG MEMORIAL AWARD (Thalberg Head). This award shall be given to a creative producer whose body of work reflects a consistently high quality of motion picture production. (See Rule Twenty-four.)

b. JEAN HERSHOLT HUMANITARIAN AWARD (Statuette). This award shall be given to an individual in the motion picture arts and sciences whose humanitarian efforts have brought credit to the industry. (See Rule Twenty-four.)

c. THE HONORARY AWARD (Statuette). This award shall be given to honor extraordinary distinction in lifetime achievement, exceptional contributions to the state of motion picture arts and sciences, or for outstanding service to the Academy. (See Rule Twenty-four.)

5. The following Special Awards may be given at such times as in the judgment of the Board of Governors there are deserving recipients, but are not necessarily given each year:

a. SPECIAL ACHIEVEMENT AWARD (Statuette). (See Rule Twenty-five.)

b. SCIENTIFIC AND TECHNICAL AWARDS. (See Rule Eighteen.)

c. GORDON E. SAWYER AWARD (Statuette). (See Rule Twenty-six.)

d. JOHN A. BONNER AWARD (Medallion). (See Rule Twenty-six.)

e. AWARD OF COMMENDATION (Special Plaque). (See Rule Twenty-six.)

f. OTHER AWARDS shall be given at such times as in the judgment of the Board of Governors there is a deserving recipient, but not necessarily each year. They shall be in such form as the Board of Governors may decide.

\section{RULE TWO ELIGIBILITY}

1. Eligibility for Academy Awards consideration is subject to Rules Two and Three, and to those special rules approved by the Board of Governors that follow.

2. All eligible motion pictures, unless otherwise noted (see Paragraph 9, below), must be:

a. feature length (defined as over 40 minutes), 
b. publicly exhibited by means of $35 \mathrm{~mm}$ or $70 \mathrm{~mm}$ film, or in a 24 - or 48 -frame progressive scan Digital Cinema format with a minimum projector resolution of 2048 by 1080 pixels, source image format conforming to ST 428-1:2006 D-Cinema Distribution Master - Image Characteristics; image compression (if used) conforming to ISO/IEC 15444-1 (JPEG 2000); and image and sound file formats suitable for exhibition in commercial Digital Cinema sites. (Blu-ray format does not meet Digital Cinema requirements.)

The audio in a Digital Cinema Package (DCP) is typically 5.1 or 7.1 channels of discrete audio. The minimum for a non-mono configuration of the audio shall be three channels as Left, Center, Right (a Left/Right configuration is not acceptable in a theatrical environment).

The audio data shall be formatted in conformance with ST 428-2:2006 D-Cinema Distribution Master - Audio Characteristics and ST 428-3:2006 D-Cinema Distribution Master - Audio Channel Mapping and Channel Labeling,

c. for paid admission in a commercial motion picture theater in Los Angeles County,

d. for a qualifying run of at least seven consecutive days, during which period screenings must occur at least three times daily, with at least one screening beginning between 6 p.m. and 10 p.m. daily,

e. advertised and exploited during their Los Angeles County qualifying run in a manner normal and customary to theatrical feature distribution practices, and

f. released within the Awards year deadlines specified in Rule Three.

3. Films that, in any version, receive their first public exhibition or distribution in any manner other than as a theatrical motion picture release will not be eligible for Academy Awards in any category. Nontheatrical public exhibition or distribution includes but is not limited to:

- Broadcast and cable television

- PPV/VOD

- DVD distribution

- Internet transmission

Motion pictures released in such nontheatrical media on or after the first day of their Los Angeles County qualifying run remain eligible. Also, ten minutes or ten percent of the running time of a film, whichever is shorter, may be shown in a nontheatrical medium prior to the film's qualifying run. (See also Paragraph 9 below.)

4. Eligibility is contingent on the receipt by the Academy of a completed Official Screen Credits (OSC) form, to be signed by the film's producer or distributor (unless waived by the Academy). DVDs or DCPs are not accepted in lieu of, or in addition to, the OSC form. The OSC form is accessible online at the Academy's Awards Submission site, submissions.oscars.org. The submission shall include:

a. full, complete and authentic screen credits,

b. the name of the Los Angeles County theater where the film has screened, and

c. the dates and times of the Los Angeles County qualifying run.

5. Eligibility for all awards shall first be determined by credits as they appear on the screen and/or as certified to the Academy by the producing companies, but final determination in any event shall be made by the Academy. The Academy shall not be bound by any contract or agreement relating to the sharing or giving of credit, and reserves the right to make its own determination of credit for purposes of Awards consideration. 
6. In the event of any dispute concerning credits, the Academy reserves the right to declare any achievement ineligible or, alternatively, to reject all claims to credit, list credits as being in controversy, and withhold any award until the dispute is resolved.

7. The alteration of an achievement by changing a picture from the version shown in Los Angeles County, upon which eligibility is based, shall subject such achievement to the risk of being declared ineligible by the Board of Governors.

8. Motion pictures from all countries shall be eligible for the annual awards listed in Rule One Paragraph 3 , as long as they satisfy the requirements of the other applicable rules, and contain Englishlanguage subtitles if released in a foreign language.

9. Exceptions to the eligibility requirements and methods of qualifying listed in Rules Two and Three appear in the Special Rules for the Animated Feature Film award (see Rule Seven), the Documentary awards (see Rule Eleven), the Foreign Language Film award (see Rule Thirteen), the Music awards (see Rule Fifteen), and the Short Film awards (see Rule Nineteen).

10. The Academy shall resolve all questions of eligibility and rules.

\section{RULE THREE THE AWARDS YEAR AND DEADLINES}

1. The required Los Angeles County qualifying run (described in Rule Two Paragraph 2) must begin between January 1, 2017, and midnight of December 31, 2017.

2. A motion picture first theatrically exhibited inside the U.S. prior to the Los Angeles County qualifying run shall be eligible for submission, provided the prior exhibition is a theatrical preview or festival screening, or takes place in a commercial motion picture theater after January 1,2016 . No nontheatrical public exhibition or distribution may occur prior to the first day of the Los Angeles County qualifying run.

3. A motion picture first theatrically exhibited outside the U.S. prior to the Los Angeles County qualifying run shall be eligible for submission, provided the prior exhibition takes place in a commercial motion picture theater after January 1, 2016. After the start of its initial theatrical engagement, a picture may be exhibited on television and other nontheatrical media, provided those exhibitions occur outside the U.S. Inside the U.S., no nontheatrical public exhibition or distribution may occur prior to the first day of the Los Angeles County qualifying run.

4. Each picture may have only one Los Angeles County qualifying run. The earliest theatrical exhibition that meets such definition shall be designated the picture's qualifying run.

5. The Official Screen Credits form and the film's full screen credits may be submitted to the Academy prior to the Los Angeles County qualifying run, but not later than 60 days after such opening. However, all Official Screen Credits forms and accompanying full screen credits must be submitted to the Academy by Friday, December 1, 2017.

6. If the film's Los Angeles County run occurs after December 1, 2017, the name of the qualifying theater and the dates and screening times of the run must be submitted to the Academy by $\mathbf{5}$ p.m. PT on Friday, December 15, 2017

7. Friday, December 15, 2017, is the last day to withdraw a film from Academy Awards consideration. 
8. Exceptions to the above eligibility periods and submission deadlines appear in the Special Rules for the Animated Feature Film award (see Rule Seven), the Documentary awards (see Rule Eleven), the Foreign Language Film award (see Rule Thirteen), and the Short Film awards (see Rule Nineteen).

\section{RULE FOUR SUBMISSION}

1. "Every award shall be conditioned upon the delivery to the Academy of one print or one copy of every film nominated for final balloting for all Academy Awards. Such print or copy shall be in a format and of a quality equivalent to the film's theatrical release; if a film exists in more than one format, then the version deposited shall be the film print. Such print or copy shall become the property of the Academy, with the proviso, however, that the Academy shall not use such print or copy for commercial gain. Such print or copy shall be deposited with the Academy and, subject to matters not within its control, shall be screened by the Academy for the membership in advance of distribution of final ballots." (Academy Bylaws, Article VIII, Section 6.)

2. "Every award shall be conditioned upon the execution and delivery to the Academy by the recipient thereof of a receipt and agreement reading as follows:

I hereby acknowledge receipt of Academy Regulations for use of the Academy Award statuette and the phrase "Academy Award(s)" in advertising. In consideration of the signing of a similar agreement by other Academy Award nominees, I agree to comply with said regulations. I understand that on (date) I may receive from you a replica of your copyrighted statuette, commonly known as the "Oscar," as an award for (category) - (film title). I acknowledge that my receipt of said replica does not entitle me to any right whatever in your copyright, trade-mark and service-mark of said statuette and that only the physical replica itself shall belong to me. In consideration of your delivering said replica to me, I agree to comply with your rules and regulations respecting its use and not to sell or otherwise dispose of it or any other "Oscar" replica I have been awarded or have received, nor permit it or any other "Oscar" replica I have been awarded or have received to be sold or disposed of by operation of law, without first offering to sell it to you for the sum of $\$ 1.00$. You shall have thirty days after any such offer is made to you within which to accept it. This agreement shall be binding not only on me, but also on my heirs, legatees, executors, administrators, estate, successors and assigns. My legatees and heirs shall have the right to acquire any "Oscar" statuette replica I have received, if it becomes part of my estate, subject to this agreement.

I agree that if I have heretofore received any Academy trophy I shall be bound by this receipt and agreement with the same force and effect as though I had executed and delivered the same in consideration of receiving such trophy." (Academy Bylaws, Article VIII, Section 7.)

3. In submitting a film for Academy Awards consideration in any category, the film's owners are deemed to have conveyed to the Academy the right to choose excerpts from the film and from all approved and available promotional materials relating to the film, including publicity stills and electronic press kits, which are submitted to the Academy in connection with the film's Awards consideration, for incorporation by the Academy at its sole discretion, into the Academy Awards telecast for the year in which the film is in competition, and into all other media content produced by the Academy relating to films submitted for Awards consideration, which is not disparaging of those films, for exhibition by the Academy and its licensees in all forms of media until 30 days following the Academy Awards telecast. The owners also convey the right to use excerpts from such films and promotional materials subsequently for any nonprofit purposes of the Academy Museum, the Academy Foundation or Academy websites, in each case subject to the Academy's compliance with all applicable guild requirements relating to such uses. The owners shall have obtained all the aforementioned rights from the talent appearing in the film, as well as all other represented personnel. Owners of 
nominated films are obligated, if requested, to submit to the Academy a high-definition digital videotape of the film in either D-5 or HDCAM format and of all approved promotional materials relating to the film, in the highest quality formats available, no later than five days following the Academy's request for such materials. The Academy will maintain all materials under appropriate security.

\section{RULE FIVE BALLOTING and NOMINATIONS}

1. Voting on all achievements shall be restricted to active and life Academy members.

2. All eligible films will be listed by the Academy on Reminder Lists of Eligible Releases for specific categories. Before the Academy makes the Reminder Lists available to voters, releasing companies may be required to check their productions as they will appear in the Reminder Lists and assume full responsibility for errors and omissions.

3. Individual reminder lists from which the nominations are voted shall refer only to the film in which the achievement was made, and not to any individual responsible, except in the case of nominations for Acting achievements, which name both the individual and the one picture wherein the achievement occurred.

4. Voting for nominations and awards shall be by secret ballot. Ballots shall be made available by the Academy, and completed ballots shall be received and tabulated by a firm of certified public accountants designated by the Academy President.

5. In the nominations voting, the marking and tabulation of all ballots shall be according to the preferential, weighted average, or reweighted range voting system. Votes for achievements in motion pictures not on the Reminder List will not be counted in the nominations balloting. Tabulation of final ballots shall be according to the plurality or preferential system. No "write-in" votes shall be counted on the final ballot.

6. Not more than five nominations shall be made for each award, except for the Best Picture award, which shall have not more than ten nor fewer than five nominations.

7. In the event a nominated achievement is declared ineligible by the Academy, it shall not be replaced, and the category will remain with one less nomination.

8. In the event that an achievement voted an award was done in collaboration, each of the eligible collaborators shall receive an award unless the number of awards is specifically limited by a category's special rules. In the event of a tie for first place in the final balloting, awards shall be given for both achievements.

9. The Board of Governors shall provide for such screenings or special meetings as may be desirable to insure a full and fair consideration of the merits of all eligible achievements.

10. Each branch or other designated committee shall be permitted to formulate its own special rules, provided the final ballot presents not more than five achievements in each category, and that nominations and final voting in each category are restricted to active and life Academy members. All rules shall be presented for approval to the Board of Governors before implementation.

11. Exceptions to the above listing in the Reminder Lists and nominations voting system appear in the Special Rules for the Animated Feature Film award (see Rule Seven), the Documentary awards (see Rule Eleven), the Foreign Language Film award (see Rule Thirteen), and the Short Film awards (see Rule Nineteen). 


\section{RULE SIX \\ SPECIAL RULES FOR THE \\ ACTING AWARDS}

1. A Reminder List including up to ten eligible actresses and up to ten eligible actors for each eligible motion picture shall be made available along with nominations ballots to all active members of the Actors Branch, who shall vote in the order of their preference for not more than five acting achievements in each category: Performance by an Actor in a Leading Role, Performance by an Actor in a Supporting Role, Performance by an Actress in a Leading Role, Performance by an Actress in a Supporting Role.

2. The five acting achievements in each category receiving the highest number of votes shall become the nominations for final voting for the Acting awards.

3. A performance by an actor or actress in any role shall be eligible for nomination either for the leading role or supporting role categories. If, however, all the dialogue has been dubbed by another actor, the performance shall not be eligible for award consideration. Singing that is dubbed will not affect the performer's eligibility unless it constitutes the entire performance. The determination as to whether a role is a leading or supporting role shall be made individually by members of the branch at the time of balloting.

4. The leading role and supporting role categories will be tabulated simultaneously. If any performance should receive votes in both categories, the achievement shall be placed only on the ballot in that category in which, during the tabulation process, it first receives the required number of votes to be nominated. In the event that the performance receives the numbers of votes required to be nominated in both categories simultaneously, the achievement shall be placed only on the ballot in that category in which it receives the greater percentage of the total votes.

5. In the event that two achievements by an actor or actress receive sufficient votes to be nominated in the same category, only one shall be nominated using the preferential tabulation process and such other allied procedures as may be necessary to achieve that result.

6. In the event that an actor or actress receives a sufficient number of votes to be nominated for one achievement in one category and for another achievement in the other category, both achievements shall be eligible.

7. Final voting for the Acting awards shall be restricted to active and life Academy members.

\section{RULE SEVEN \\ SPECIAL RULES FOR THE ANIMATED FEATURE FILM AWARD}

\section{DEFINITION}

An animated film is defined as a motion picture in which movement and characters' performances are created using a frame-by-frame technique, and usually falls into one of the two general fields of animation: narrative or abstract. Some of the techniques of animating films include but are not limited to hand-drawn animation, computer animation, stop-motion, clay animation, pixilation, cutout animation, pinscreen, camera multiple pass imagery, kaleidoscopic effects created frame-by-frame, and drawing on the film frame itself. Motion capture and real-time puppetry are not by themselves animation techniques. An animated short film has a running time of $\mathbf{4 0}$ minutes or less. An animated feature film has a running time of more than 40 minutes. In an animated film, animation must figure in no less than 75 percent of the picture's running time. In addition, a narrative animated film must have a significant number of the 
major characters animated. If the picture is created in a cinematic style that could be mistaken for live action, the filmmaker(s) must also submit information supporting how and why the picture is substantially a work of animation rather than live action.

\section{ELIGIBILITY}

A. Except as indicated above, motion pictures in this category must meet all the requirements in Academy Awards Rules Two, Three and Four.

B. At least eight eligible animated features must have been theatrically released in Los Angeles County within the calendar year for this category to be activated.

\section{SUBMISSION}

A. An entry form naming the intended award recipient(s) and including the signatures of all the credited producer(s) and director(s) is required. This is to insure that all parties are properly informed, and that agreement on the designated award recipient(s) is settled prior to submission.

B. The award recipient(s) shall be designated by those responsible for the production of the film. The designated recipient(s) must be the KEY CREATIVE INDIVIDUAL(S) most clearly responsible for the overall achievement. A maximum of two persons may be designated as nominees, one of whom must be the credited director and the other of whom must have a producer credit ("producer" or "produced by"). The Short Films and Feature Animation Branch Executive Committee has the right to name a third nominee only in the case of a TWO-PERSON TEAM with shared and equal director credit, in which case a third statuette may be awarded.

C. The print or DCP submitted for Academy Awards consideration must be identical in content and length to the print or DCP used for the qualifying exhibition.

D. The following submission materials, including those from non-U.S. entrants, must be received by The Academy by 5 p.m. on Wednesday, November 1, 2017:

- Completed online submission form

- $35 \mathrm{~mm}$ or $70 \mathrm{~mm}$ film print or DCP

- Digital content delivery

- 200 DVDs of the entry, without trailers or other extraneous material, capable of playing on Region O/NTSC standard definition DVD players. DVDs must be in individual paper sleeves and must include the title, running time and director name only. No artwork, contact information, company name or film logo is acceptable on the DVD labels or sleeves.

- Full cast and credit list

- Brief English-language synopsis of the film

- Biography, filmography and photograph of each key creative individual

- 3 to 5 representative film stills

- A poster from the film's original release

Foreign-language entries must provide accurate, legible English-language subtitles.

E. Submissions must be shipped prepaid to:

Academy of Motion Picture Arts and Sciences

ANIMATED FEATURE ENTRY

8949 Wilshire Blvd.

Beverly Hills, CA 90211 
Those entries not chosen as nominations for final balloting will be returned to the sender at the Academy's expense. Prints or DCPs, screeners and digital content submitted will be retained by the Academy until the voting process is completed and will not be loaned out for use.

F. Films submitted in the Animated Feature Film category may qualify for Academy Awards in other categories, including Best Picture, provided they comply with the rules governing those categories.

G. An animated feature film may be submitted in only one Awards year for Academy Awards consideration.

\title{
IV. VOTING
}

A. A chairperson, appointed by the Academy President, shall head the Animated Feature Nominating Committee. An invitational letter will be sent to all active and life Academy members, requesting their participation. Those serving on the committee will be required to see a minimum percentage of submitted eligible films as defined by the then-current procedures.

B. All submitted eligible films will be made available to the Animated Feature Nominating Committee. The committee will vote by secret ballot to nominate from 2 to 5 motion pictures for this award. In any year in which 8 to 12 animated feature films are released in Los Angeles County and submitted for consideration, either 2 or 3 motion pictures may be nominated. In any year in which 13 to 15 animated feature films are released and submitted, a maximum of 4 motion pictures may be nominated. In any year in which 16 or more animated feature films are released and submitted, a maximum of 5 motion pictures may be nominated.

1. The Nominating Committee members shall vote in the order of their preference for not more than five motion pictures.

C. The Short Films and Feature Animation Branch Executive Committee shall have the right and responsibility to resolve all questions of eligibility, rules and the designation of award recipients.

D. Final voting for the Animated Feature Film award shall be restricted to active and life Academy members.

\section{RULE EIGHT \\ SPECIAL RULES FOR THE CINEMATOGRAPHY AWARD}

1. A Reminder List of all eligible motion pictures shall be made available along with a nominations ballot to all members of the Cinematographers Branch, who shall vote in the order of their preference for not more than five motion pictures.

2. The five productions receiving the highest number of votes shall become the nominations for final voting for the Cinematography award.

3. In accordance with Rule Two Paragraph 5, only principal position credit(s) shall be considered eligible for the Cinematography award.

4. Final voting for the Cinematography award shall be restricted to active and life Academy members.

\author{
RULE NINE \\ SPECIAL RULES FOR THE \\ COSTUME DESIGN AWARD
}


1. A Reminder List of all eligible motion pictures shall be made available along with a nominations ballot to all members of the Costume Designers Branch, who shall vote in the order of their preference for not more than five motion pictures.

2. To be eligible for the Costume Design award, the costumes for the picture must have been conceived by a costume designer. It is the intention of this rule to recognize the designing of costumes for their special use in motion pictures. Eligibility shall be determined by the Costume Designers Branch members present at a meeting called specifically for that purpose prior to the start of nominations balloting.

3. In accordance with Rule Two Paragraph 5, only principal position credit(s) shall be considered eligible for the Costume Design award.

4. The five motion pictures receiving the highest number of votes shall become the nominations for final voting for the Costume Design award.

5. Final voting for the Costume Design award shall be restricted to active and life Academy members.

\section{RULE TEN \\ SPECIAL RULES FOR THE \\ DIRECTING AWARD}

1. A Reminder List of all eligible motion pictures shall be made available along with a nominations ballot to all members of the Directors Branch, who shall vote in the order of their preference for not more than five productions.

2. The five motion pictures receiving the highest number of votes shall become the nominations for final voting for the Directing award.

3. Final voting for the Directing award shall be restricted to active and life Academy members.

\section{RULE ELEVEN \\ SPECIAL RULES FOR THE \\ DOCUMENTARY AWARDS}

\section{DEFINITION}

An eligible documentary film is defined as a theatrically released nonfiction motion picture dealing creatively with cultural, artistic, historical, social, scientific, economic or other subjects. It may be photographed in actual occurrence, or may employ partial reenactment, stock footage, stills, animation, stop-motion or other techniques, as long as the emphasis is on fact and not on fiction.

\section{CATEGORIES}

The Documentary awards are divided into two categories:

A. Documentary Feature - motion pictures with a running time of more than 40 minutes, and

B. Documentary Short Subject - motion pictures with a running time of 40 minutes or less, including all credits.

\section{DOCUMENTARY FEATURE}




\section{A. Eligibility}

1. To be eligible for 90th Academy Awards consideration, a documentary feature must complete both a seven-day theatrical release in Los Angeles County and a seven-day theatrical release in the City of New York during the eligibility period.

2. The eligibility period for documentary features begins on January 1,2017 , and ends on December 31, 2017. For films being released between January 1 and August 20, the completed online submission form and all other entry materials, including the digital content delivery and DVDs, must be received by the Academy no later than 30 days after the end of the qualifying theatrical releases. For films being released between August 21 and December 31, the completed online submission form, letters from the theaters confirming that the film will be satisfying the release requirements, and all other entry materials, including the digital content delivery and DVDs, must be received by the Academy by $\mathbf{5}$ p.m. PT on Wednesday, September 20, 2017. Those entrants submitting entry materials by September 20 with a planned theatrical release before the end of the calendar year, but which will not have a locked picture by the September 20 deadline, may request by September 13 an extension for the DVD submission and digital content delivery only. Extensions will be granted only to October 20, and only if the picture is not locked. There will be no exceptions.

3. The theatrical releases in both cities must take place in the same eligibility period and within two years of the motion picture's completion date. A theatrical release in only one of the qualifying cities disqualifies a picture from Academy Awards contention in the Documentary Feature category in any year. Documentaries submitted for consideration for the 90th Academy Awards in any category will not be eligible for consideration in subsequent Awards years in any category. The picture must be submitted in the same Awards year in which it first qualifies.

4. The picture must be exhibited using $35 \mathrm{~mm}$ or $70 \mathrm{~mm}$ film, or in a 24 - or 48 -frame progressive scan Digital Cinema format with a minimum projector resolution of 2048 by 1080 pixels, source image format conforming to ST 428-1:2006 D-Cinema Distribution Master - Image Characteristics; image compression (if used) conforming to ISO/IEC 15444-1 (JPEG 2000); and image and sound file formats suitable for exhibition in commercial Digital Cinema sites.

The audio in a Digital Cinema Package (DCP) is typically 5.1 or 7.1 channels of discrete audio. The minimum for a non-mono configuration of the audio shall be three channels as Left, Center, Right (a Left/Right configuration is not acceptable in a theatrical environment).

The audio data shall be formatted in conformance with ST 428-2:2006 D-Cinema Distribution Master - Audio Characteristics and ST 428-3:2006 D-Cinema Distribution Master - Audio Channel Mapping and Channel Labeling.

5. Screenings during the theatrical release must occur at least four times daily and must begin between noon and 10 p.m., with at least one screening beginning daily between 6 p.m. and 10 p.m. The motion picture must be exhibited for paid admission, and must be advertised during each of its qualifying theatrical releases in at least one of these major newspapers in each city: The New York Times, Time Out New York or The Village Voice (New York); Los Angeles Times or LA Weekly (Los Angeles). The film must have a movie critic review in either The New York Times and/or Los Angeles Times. A television critic review will not be accepted. Filmmakers who are unable to obtain a review may appeal for an exemption. Advertisements must have minimum dimensions of one inch by two inches and must include the theater, film title, and the dates and screening times of the qualifying exhibitions. A listing in the theater grid will not meet this requirement. Advertising must begin on the first day of the theatrical release.

6. Works that are essentially promotional or instructional are not eligible, nor are works that are 
essentially unfiltered records of performances.

7. Only individual documentary works are eligible. This excludes from consideration:

- multi-part or limited series,

- episodes extracted from a larger series,

- $\quad$ segments taken from a single "composite" program, and

- alternate versions of ineligible works.

8. The significant dialogue or narration must be in English, or the entry must have English-language subtitles.

9. Films that, in any version, receive a nontheatrical public exhibition or distribution before their first qualifying theatrical release, will not be eligible for Academy Awards

consideration. Nontheatrical public exhibition or distribution includes but is not limited to:

- Broadcast and cable television

- PPV/VOD

- DVD distribution

- Internet transmission

Ten minutes or ten percent of the running time of a film, whichever is shorter, is allowed to be shown in a nontheatrical medium prior to the film's theatrical release.

\section{B. Submission}

1. The producer or distributor of the film must register online at the Academy's Awards Submissions site, submissions.oscars.org, and inform the Academy of the details of the film's theatrical release before the release begins.

2. Entrants (including non-U.S. entrants) must complete the online submission form and submit to the Academy the digital content delivery of the film and 100 DVDs of the entry, without trailers or other extraneous material, capable of playing on Region 0/NTSC standard definition DVD players, and all other required material and required signatures by 5 p.m. PT on the dates listed in Paragraph III.A.2 above. DVDs must be in individual paper sleeves and must include the title, running time and director name only. No artwork, contact information, company name or film logo is acceptable on the DVD labels or sleeves.

\section{Voting}

1. Documentaries will be viewed by members of the Documentary Branch, which will use a preferential voting system to produce a shortlist of 15 films. Five nominees will then be chosen by a second round of balloting, again using a preferential voting system.

2. Final voting shall be restricted to active and life members of the Academy who have viewed all of the nominated documentaries.

\section{Copies Required}

The filmmakers of the shortlisted documentaries must submit either two $35 \mathrm{~mm}$ or $70 \mathrm{~mm}$ film prints or two DCP versions of the documentary after the shortlist is announced. Following the nominations screenings, one copy of the work shall become the property of the Academy Film Archive. By submitting a film, the filmmaker agrees that the Academy has the right to make copies and distribute them for voting purposes only. 


\section{E. Nominees and Award Recipients}

1. The nominee(s) should be the individual(s) most involved in the key creative aspects of the filmmaking process. A maximum of two persons may be designated as nominees, one of whom must be the credited director who exercised directorial control, and the other of whom must have a producer or director credit. If a producer is named, that individual must have performed a major portion of the producing functions, in accordance with Academy producer criteria. Production companies or persons with the screen credit of executive producer, coproducer or any credit other than director or producer shall not be eligible as nominees for the motion picture.

2. All individuals with a "producer" or "produced by" credit on films that reach the semifinal round will automatically be vetted. The Documentary Branch Executive Committee will determine which producers, if any, are eligible to receive an Oscar. In the unlikely event of a dispute, filmmakers may appeal the committee's decision.

3. No more than two statuettes will normally be given in the Documentary Feature category. On occasion, a third statuette may be awarded when there are three primary and essential contributors.

\section{F. Advertising and Publicity Restrictions}

Only documentaries that receive nominations or Academy Awards may refer to their Academy endorsements in advertising and publicity materials. A film that is selected for the shortlist may not identify itself as an "Academy Award finalist," "Academy Award shortlist film" or the like except when it appears in a program consisting entirely of such films.

\section{G. Other Rules}

1. Documentaries submitted in this category may also qualify for awards in other categories if they meet the specified requirements.

2. The Documentary Branch Executive Committee shall resolve all questions of eligibility and rules.

\section{DOCUMENTARY SHORT SUBJECT}

\section{A. Eligibility}

1. To be eligible for 90th Academy Awards consideration, a documentary short subject must complete a seven-day commercial run in a theater in either Los Angeles County or the City of New York, during the eligibility period and prior to public exhibition or distribution by any nontheatrical means.

\section{OR}

2. The film must have won a qualifying award at a competitive film festival, as specified in the Documentary Short Subject Qualifying Festival List, regardless of any prior public exhibition or distribution by nontheatrical means. Proof of the award must be submitted with the entry. The Documentary Short Subject Qualifying Festival List is available at www.oscars.org or may be obtained from the Academy.

\section{OR}

3. The film must have won a Gold, Silver or Bronze Medal award in the Academy's 2017 Student Academy Awards competition in the Documentary category. 
4. The eligibility period for documentary short subjects begins on September 1, 2016, and ends on August 31, 2017. The completed online submission form and all other entry materials, including the digital content delivery and DVDs, must be received by the Academy no later than 30 days after the end of the qualifying run or the festival award win. No submissions will be accepted after 5 p.m. PT on Friday, September 1, 2017.

5. The qualifying run or festival award win must take place within two years of the motion picture's completion date. The picture must be submitted in the same Awards year in which it first qualifies. Documentaries submitted for the 90th Academy Awards in any category will not be eligible for consideration in subsequent Awards years in any category.

6. The picture must be exhibited using $35 \mathrm{~mm}$ or $70 \mathrm{~mm}$ film, or in a 24 - or 48 -frame progressive scan Digital Cinema format with a minimum projector resolution of 2048 by 1080 pixels, source image format conforming to ST 428-1:2006 D-Cinema Distribution Master - Image Characteristics; image compression (if used) conforming to ISO/IEC 15444-1 (JPEG 2000); and image and sound file formats suitable for exhibition in commercial Digital Cinema sites.

The audio in a Digital Cinema Package (DCP) is typically 5.1 or 7.1 channels of discrete audio. The minimum for a non-mono configuration of the audio shall be three channels as Left, Center, Right (a Left/Right configuration is not acceptable in a theatrical environment).

The audio data shall be formatted in conformance with ST 428-2:2006 D-Cinema Distribution Master - Audio Characteristics and ST 428-3:2006 D-Cinema Distribution Master - Audio Channel Mapping and Channel Labeling.

7. Screenings in the qualifying run must occur at least once daily and begin between noon and 10 p.m. The motion picture must be exhibited for paid admission, and must be advertised during its run in a major newspaper: The New York Times, Time Out New York or The Village Voice (New York); Los Angeles Times or LA Weekly (Los Angeles). Advertisements must have minimum dimensions of one inch by two inches and must include the theater, film title, and the dates and screening times of the qualifying exhibition. A listing in the theater grid will not meet this requirement. Advertising must begin on the first day of the qualifying run.

8. Works that are essentially promotional or instructional are not eligible, nor are works that are essentially unfiltered records of performances.

9. Only individual documentary works are eligible. This excludes from consideration such works as:

- multi-part or limited series,

- episodes extracted from a larger series,

- segments taken from a single "composite" program,

- alternate versions of ineligible works, and

- documentary short subjects created from materials substantially taken from or cut down from completed, publicly exhibited feature-length documentaries.

10. The significant dialogue or narration must be in English, or the entry must have English-language subtitles.

11. Films that, in any version, receive a nontheatrical public exhibition or distribution before their qualifying run as defined in Paragraph IV.A.1 above will not be eligible for Academy Awards consideration. Nontheatrical public exhibition or distribution includes but is not limited to:

- Broadcast and cable television

- PPVIVOD 
- DVD distribution

- Internet transmission

Up to ten percent of the running time of a film is allowed to be shown in a nontheatrical medium prior to the film's commercial qualifying run.

Films qualifying under Paragraph IV.A.2 or IV.A.3 above are exempted from this rule.

\section{B. Submission}

1. The producer or distributor of the film must register online at the Academy's Awards Submissions site, submissions.oscars.org, and inform the Academy of the details of the film's qualifying run before the run begins.

2. Entrants (including non-U.S. entrants) must complete the online submission form and submit to the Academy the digital content delivery of the film and 100 DVDs of the entry, without trailers or other extraneous material, capable of playing on Region 0/NTSC standard definition DVD players, and all other required materials and required signatures by 5 p.m. PT on the dates listed in Paragraph IV.A.4 above. DVDs must be in individual paper sleeves and must include the title, running time and director name only. No artwork, contact information, company name or film logo is acceptable on the DVD labels or sleeves.

\section{Voting}

1. Documentaries will be viewed by members of the Documentary Branch, who will use a preferential voting system to produce a ten-picture shortlist. Five nominees will then be chosen by a second round of balloting, using a preferential voting system.

2. Final voting shall be restricted to active and life Academy members who have viewed all of the nominated documentaries.

\section{Copies Required}

The filmmakers of the shortlisted documentaries must submit either two $35 \mathrm{~mm}$ or $70 \mathrm{~mm}$ film prints or two DCP versions of the documentary after the shortlist is announced. Following the nominations screenings, one copy of the work shall become the property of the Academy Film Archive. By submitting a film, the filmmaker agrees that the Academy has the right to make copies and distribute them for voting purposes only.

\section{E. Nominees and Award Recipients}

1. The nominee(s) should be the individual(s) most involved in the key creative aspects of the filmmaking process. A maximum of two persons may be designated as nominees, one of whom must be the credited director who exercised directorial control, and the other of whom must have a producer or director credit. If a producer is named, that individual must have performed a major portion of the producing functions, in accordance with Academy producer criteria. Production companies or persons with the screen credit of executive producer, coproducer or any credit other than director or producer shall not be eligible as nominees for the motion picture.

2. All individuals with a "producer" or "produced by" credit on films that reach the semifinal round will automatically be vetted. The Documentary Branch Executive Committee will determine which producer, if any, is eligible to receive an Oscar. In the unlikely event of a dispute, filmmakers may appeal the Committee's decision.

\section{F. Advertising and Publicity Restrictions}


Only documentaries that receive nominations or Academy Awards may refer to their Academy endorsements in advertising and publicity materials. A film that is selected for the shortlist may not identify itself as an "Academy Award finalist," "Academy Award shortlist film" or the like except when it appears in a program consisting entirely of such films.

\section{G. Other Rules}

The Documentary Branch Executive Committee shall resolve all questions of eligibility and rules.

\section{RULE TWELVE SPECIAL RULES FOR THE FILM EDITING AWARD}

1. A Reminder List of all eligible motion pictures shall be made available along with a nominations ballot to all members of the Film Editors Branch, who shall vote in the order of their preference for not more than five productions.

2. The five productions receiving the highest number of votes shall become the nominations for final voting for the Film Editing award.

3. In accordance with Rule Two Paragraph 5, only film editors who hold principal position credit(s) shall be considered eligible for the Film Editing award.

4. Final voting for the Film Editing award shall be restricted to active and life Academy members.

\section{RULE THIRTEEN SPECIAL RULES FOR THE FOREIGN LANGUAGE FILM AWARD}

\section{A. DEFINITION}

A foreign language film is defined as a feature-length motion picture (defined as over 40 minutes) produced outside the United States of America with a predominantly non-English dialogue track. Animated and documentary feature films are permitted.

\section{B. ELIGIBILITY}

1. The motion picture must be first released in the country submitting it no earlier than October 1,2016 , and no later than September 30, 2017, and be first publicly exhibited for at least seven consecutive days in a commercial motion picture theater for the profit of the producer and exhibitor. Submissions must be in $35 \mathrm{~mm}$ or $70 \mathrm{~mm}$ film, or in a 24 - or 48 -frame progressive scan Digital Cinema format with a minimum projector resolution of 2048 by 1080 pixels, source image format conforming to ST 4281:2006 D-Cinema Distribution Master - Image Characteristics; image compression (if used) conforming to ISO/IEC 15444-1 (JPEG 2000); and image and sound file formats suitable for exhibition in commercial Digital Cinema sites.

The audio in a Digital Cinema Package (DCP) is typically 5.1 or 7.1 channels of discrete audio. The minimum for a non-mono configuration of the audio shall be three channels as Left, Center, Right (a Left/Right configuration is not acceptable in a theatrical environment). 
The audio data shall be formatted in conformance with ST 428-2:2006 D-Cinema Distribution Master - Audio Characteristics and ST 428-3:2006 D-Cinema Distribution Master - Audio Channel Mapping and Channel Labeling.

2. The film must be advertised and exploited during its theatrical release in a manner considered normal and customary to theatrical feature distribution practices. The film need not have been released in the United States.

3. Films that, in any version, receive a nontheatrical public exhibition or distribution before their first qualifying theatrical release will not be eligible for Academy Awards consideration. Nontheatrical public exhibition or distribution includes but is not limited to:

- Broadcast and cable television

- $\quad$ PPVIVOD

- DVD distribution

- Internet transmission

4. The recording of the original dialogue track as well as the completed picture must be predominantly in a language or languages other than English. Accurate, legible English-language subtitles are required.

5. The submitting country must certify that creative control of the motion picture was largely in the hands of citizens or residents of that country.

6. The Foreign Language Film Award Executive Committee shall resolve all questions of eligibility and rules.

\section{SUBMISSION}

1. Each country shall be invited to submit its best film to the Academy. Selection of that film shall be made by one approved organization, jury or committee that should include artists and/or craftspeople from the field of motion pictures. A list of the selection committee members must be submitted to the Academy no later than Wednesday, August 16, 2017. Countries submitting for the first time, or which have not submitted for the previous five years, must present a list of selection committee members for Academy approval by Wednesday, March 14, 2018, for eligibility in the following (91st) Awards year. A country need not submit a film every year.

2. Only one film will be accepted from each country as the official selection.

3. The Academy will provide online access to each country's approved selection committee so that the producer of the selected film can supply full production information.

4. The following submission materials must be submitted to the Academy by $\mathbf{5}$ p.m. PT on Monday, October 2, 2017:

- Completed online submission forms

- $35 \mathrm{~mm}$ or $70 \mathrm{~mm}$ film print or DCP with accurate, legible English-language subtitles. The print or DCP submitted for Awards consideration must be identical in content and length to the print or copy used in the film's theatrical release.

- Digital content delivery

- Full cast and credits list

- Brief English-language synopsis of the film

- Director's biography, filmography and photograph

- 3 to 5 representative film stills

- A poster from the film's theatrical release 
- Proof of advertising for the film's theatrical release

5. Countries whose films are shortlisted will be required to provide the Academy two additional Englishlanguage subtitled prints or DCPs, to facilitate voting screenings. The two additional prints or DCPs are due at the Academy by $\mathbf{9}$ a.m. PT on the Thursday after the shortlist is announced.

6. Films submitted will be retained by the Academy throughout the voting process. By submitting a film, the filmmaker agrees that the Academy has the right to make copies and distribute them for voting purposes only. The Academy will retain for its archives one print of every motion picture receiving a nomination for the Foreign Language Film award. Additional prints of those films receiving nominations will be returned to the sender at the Academy's expense.

D. VOTING

1. Foreign Language Film nominations will be determined in two phases:

a. The Phase I Foreign Language Film Award Committee will view the eligible submissions in the category and vote by secret ballot. The group's top six choices, augmented by three additional selections voted by the Academy's Foreign Language Film Award Executive Committee, will constitute the shortlist of nine films.

b. The Phase II Foreign Language Film Award Committee will view the nine shortlisted films and vote by secret ballot to determine the category's five nominees.

2. Final voting for the Foreign Language Film award shall be restricted to active and life Academy members who have viewed all five motion pictures nominated for the award.

3. The Academy statuette (Oscar) will be awarded to the motion picture and accepted by the director on behalf of the picture's creative talents. For Academy Awards purposes, the country will be credited as the nominee. The director's name will be listed on the statuette plaque after the country and film title.

\section{E. ADVERTISING AND PUBLICITY RESTRICTIONS}

1. Only motion pictures that receive nominations or Academy Awards may refer to their Academy endorsements in advertising and publicity materials. A motion picture that is selected for inclusion in the semifinal round of competition may not identify itself as an "Academy Award finalist," "Academy Award shortlist film" or the like in its individual marketing or publicity.

2. In addition to complying with the Awards Rules for the 90th Oscars, all participants in the Awards competition are also bound by the Academy Campaign Regulations concerning the promotion of eligible films and are subject to the penalties provided therein, including the potential declaration of ineligibility by the Board of Governors for violation of those guidelines. The Regulations can be found at Oscars.org/regulations.

\section{F. ELIGIBILITY IN OTHER CATEGORIES}

1. Eligible submissions for Foreign Language Film award consideration may also qualify for the 90th Academy Awards in other categories, provided they comply with the rules governing those categories.

2. In order to qualify for other categories, the motion pictures must be publicly exhibited by means of $35 \mathrm{~mm}$ or $70 \mathrm{~mm}$ film or in the digital format specified in Paragraph B.1 above for paid admission (previews excluded) in a commercial motion picture theater in Los Angeles County, for a qualifying run of at least seven consecutive days, during which period screenings must occur at least three 
times daily, with at least one screening beginning between 6 p.m. and 10 p.m. daily. The qualifying run must begin between January 1, 2017, and midnight of December 31, 2017.

3. Motion pictures nominated for the Foreign Language Film award shall not be eligible for Academy Awards consideration in any category in any subsequent Awards year. Submitted films that are not nominated for the Foreign Language Film award are eligible for Awards consideration in other categories in the subsequent year, provided the pictures begin their seven-day qualifying run in Los Angeles County during that calendar year.

\section{RULE FOURTEEN SPECIAL RULES FOR THE MAKEUP AND HAIRSTYLING AWARD}

\section{DEFINITION}

Makeup refers to any change in the appearance of a performer's face, head, or body created by the application of cosmetics, three-dimensional materials, prosthetic appliances, or facial hair applied directly to the performer's face, head, or body. Hairstyling refers to any change in the appearance of a performer through hairstyling, wigs or hairpieces applied directly to the performer.

Makeup and hairstyling, as achievements or crafts, shall be determined by the Makeup Artists and Hairstylists Branch Executive Committee.

\section{ELIGIBILITY AND VOTING}

A. Makeup Artists and Hairstylists Branch members of the Academy shall attend meetings to review a Reminder List of all eligible motion pictures. Selected credited makeup artists and hairstylists of the motion pictures under consideration for the Makeup and Hairstyling award shall be required to provide the committee with written descriptions explaining the procedures used to create the makeup and hairstyling achievements, and the names and titles of the primary individuals - not to exceed three in number - directly involved with, and principally responsible for, the makeup and hairstyles achieved.

No more than two statuettes will normally be given in the Makeup and Hairstyling category. On occasion, a third statuette may be awarded when there are three primary and essential contributors to the achievement.

B. The Makeup Artists and Hairstylists Branch members shall meet and vote by secret ballot in the order of their preference for not more than seven motion pictures to be considered for the Makeup and Hairstyling award. A minimum of 15 eligible voters shall constitute a quorum for the selection of achievements to be considered further. Recommendations will be made to the Makeup Artists and Hairstylists Branch Executive Committee for specific individual achievements from each picture to be considered for the award.

C. The Executive Committee will request that producers provide opportunities to view their motion pictures through advance screenings or screeners. This is especially encouraged in instances where a film will be released after the selection meeting to determine the seven pictures that will be considered for nomination. If, and only if, the film is not available by two weeks prior to the selection meeting, excerpts may be submitted.

D. The producers, or directors, and responsible makeup artists and hairstylists of the motion pictures selected for Awards consideration shall be required to provide the committee with film or digital excerpts of selected scenes showing the achievements. If a motion picture is shortlisted, the Academy will provide a list of format requirements. For archival purposes, an archival key (aka DKDM) for the composition playlist must also be provided. Excerpts must be from the final release 
version of the motion pictures and shall not exceed ten minutes in total running time. All elements of the excerpt should be presented exactly as they appeared in the final release version of the motion picture and should focus on the makeup and hairstyling achievements under consideration. Each excerpt must start and finish without an editorial or sound blend between excerpts. If the clip does not meet these requirements, it may not be shown.

The producers shall provide the Academy the right to use the excerpts for any voting purposes, and for any nonprofit purposes of the Academy Museum, the Academy Foundation or Academy websites.

E. For nomination purposes, eligibility of the contributor(s) to the makeup and/or hairstyling achievement shall be determined by the Makeup Artists and Hairstylists Branch Executive Committee.

F. Makeup Artists and Hairstylists Branch members shall meet to screen the excerpts from the motion pictures (see Paragraph II.D above). All Makeup Artists and Hairstylists Branch members who have seen all seven of the shortlisted films will receive ballots and shall vote in the order of their preference for not more than three motion pictures. The three pictures receiving the highest number of votes shall become the nominations for final voting for the Makeup and Hairstyling award.

Makeup Artists and Hairstylists Branch members unable to attend the voting screening, but who have seen all the motion pictures under consideration, will receive ballots by mail. These ballots must be returned no later than the day preceding the voting screening.

G. Final voting for the Makeup and Hairstyling award shall be restricted to active and life Academy members.

$\mathrm{H}$. Such other rules or modifications as may be necessary for the proper conduct of this award shall be adopted by the Makeup Artists and Hairstylists Branch Executive Committee, subject to the approval of the Academy Board of Governors.

\section{RULE FIFTEEN \\ SPECIAL RULES FOR THE MUSIC AWARDS}

\section{CATEGORIES}

\section{A. Original Score:}

An original score is a substantial body of music that serves as original dramatic underscoring and is written specifically for the motion picture by the submitting composer(s).

\section{B. Original Song:}

An original song consists of words and music, both of which are original and written specifically for the motion picture. There must be a clearly audible, intelligible, substantive rendition (not necessarily visually presented) of both lyric and melody, used in the body of the motion picture or as the first music cue in the end credits.

\section{Original Musical:}

An original musical consists of not fewer than five original songs (as defined in Paragraph I.B above) by the same writer or team of writers, either used as voiceovers or visually performed. Each of these songs must be substantively rendered, clearly audible, and intelligible, and must further the storyline of the motion picture. An arbitrary group of songs unessential to the storyline will not be considered eligible. 


\section{ELIGIBILITY}

A. The work must be created specifically for the eligible feature-length motion picture.

B. The work must be the result of a creative interaction between the filmmaker(s) and the composer(s) and/or songwriter(s) who have been engaged to work directly on the motion picture.

C. The work must be recorded for use in the motion picture prior to any other usage, including public performance or exploitation through any media whatsoever.

D. Only the principal composer(s) or songwriter(s) responsible for the conception and execution of the work as a whole shall be eligible for an award. Expressly excluded from eligibility are all of the following:

1. music supervisors

2. partial contributors (i.e., any writer not responsible for the overall design of the work)

3. contributors working on speculation

4. producers and/or arrangers not responsible for the creation of the original song or score

E. A score shall not be eligible if:

1. it has been diluted by the use of pre-existing music, or

2. it has been diminished in impact by the predominant use of songs or any music not composed specifically for the film by the submitting composer, or

3. it has been assembled from the music of more than one composer.

F. No more than one statuette will normally be given in the Original Score category. A second statuette may be awarded when two credited composers function as equal collaborators, each contributing fully to the original dramatic underscore for the film. In cases where three or more credited composers function as equal collaborators, a single statuette may be awarded to the group. Each composer must agree to the single "group statuette" option by signing and returning a Group Award form prior to the submission deadline. Final determination of the awardable composers in the group will be made by the Music Branch Executive Committee.

G. No more than two statuettes will normally be given in the Original Song category. A third statuette may be awarded when there are three essentially equal writers of a song. The Music Branch Executive Committee has the right, in what it alone determines to be a very rare and extraordinary circumstance, to award a fourth statuette. In cases where an established musical group has authored a song, a single statuette may be awarded under the group name in place of individual statuettes for each songwriter. Each of the credited songwriters must agree to the single "group statuette" option by signing and returning a Group Award form prior to the submission deadline. Requests for a group statuette are subject to final approval by the Music Branch Executive Committee.

$\mathrm{H}$. In the case of an original musical, the composer or adapter of the instrumental score may qualify for an award if his or her contribution is deemed relevant and substantial.

I. The Music Branch Executive Committee shall resolve all rules interpretations and all questions of eligibility.

J. It is within the sole and confidential discretion of the Board of Governors to determine what awards, if any, shall be given. 


\section{SUBMISSION}

A. For an achievement to be eligible for nomination in any of the Music categories, the submission must be initiated either personally by the songwriter or composer, or by their authorized representative, such as a manager or an assistant.

B. Submission forms must be signed by all submitting writers and must be accompanied by a complete final music cue sheet listing all music cues. Original Song submissions must further be accompanied by a vocal lead sheet and a video clip (DVD, Digibeta or digital files are acceptable) of no more than three minutes of each song, showing how the song is used in the motion picture.

C. The composer's on-screen credit and submission form, as well as the actual cue sheet for the music as used in the film and supplied by the film company, shall be used by the Music Branch Executive Committee to help determine the eligibility of the score.

D. Submissions may be made prior to the film's Los Angeles County qualifying run, but must be made no later than 60 days after such opening, or by 5 p.m. PT on Friday, December 1, 2017, whichever comes first.

E. The Music Branch Executive Committee has the right, but not the obligation, to submit any eligible works in all three categories, but must do so no later than Friday, December 8, 2017.

\section{VOTING}

A. Works shall be judged on their effectiveness, craftsmanship, creative substance and relevance to the dramatic whole, and only as presented within the motion picture. Extended, revised, enhanced or alternate versions outside of the film shall not be considered.

B. A Reminder List of works submitted and a nominations ballot for the Original Score category (and Original Musical category, if activated) will be made available to all members of the Music Branch, who shall vote in the order of their preference for not more than five achievements in each category.

C. A Reminder List of works submitted in the Original Song category and a compilation of the song clips will be sent to all members of the Music Branch, who shall watch the clips and then vote in the order of their preference for not more than five achievements in the category.

D. In all three categories, the five achievements receiving the highest number of votes will become the nominations for final voting for the award.

E. A maximum of two songs may be nominated from any one film. If more than two songs from a film are in contention, the two songs with the most votes will be the nominees.

F. If there are 25 or fewer qualified works submitted in any category, the Music Branch Executive Committee may recommend to the Board of Governors that nominations be limited to three. If there are nine or fewer qualifying works submitted in any category, the Executive Committee may recommend to the Board of Governors that no award be given in that category for the current Awards year.

G. The category of Original Musical may be activated only by special request of the Music Branch Executive Committee to the Board of Governors in a year when the field of eligible submissions is determined to be of sufficient quantity and quality to justify award competition.

H. Final voting for each category shall be restricted to active and life Academy members. 


\section{RULE SIXTEEN \\ SPECIAL RULES FOR THE \\ BEST PICTURE OF THE YEAR AWARD}

1. A Reminder List of all eligible motion pictures shall be made available along with a nominations ballot to all active and life members of the Academy who shall vote in the order of their preference for not more than five pictures.

2. The pictures receiving the highest number of votes shall become the nominations for final voting for the Best Picture award. There may not be more than ten nor fewer than five nominations; however, no picture shall be nominated that receives less than five percent of the total votes cast.

3. The individual(s) who shall be credited for Academy Award purposes must have screen credit of "producer" or "produced by." Persons with screen credits of executive producer, co-producer, associate producer, line producer, produced in association with or any other credit shall not receive nominations or Academy statuettes. The nominees will be those three or fewer producers who have performed the major portion of the producing functions. In determining the number of producers eligible for nomination, a bona fide team of not more than two people shall be considered to be a single "producer" if the two individuals have had an established producing partnership as determined by the PGA's Producing Partnership Panel. To qualify as a producer nominee for a nominated picture, the producer must have been determined eligible for a PGA award for the picture, or have appealed the PGA's refusal of such eligibility. Final determination of the qualifying producer nominees for each nominated picture will be made by the Producers Branch Executive Committee, including the right to name any additional qualified producer as a nominee.

4. The Producers Branch Executive Committee shall resolve all questions of eligibility and rules.

5. Final voting for the Best Picture award shall be restricted to active and life Academy members.

\section{RULE SEVENTEEN SPECIAL RULES FOR THE PRODUCTION DESIGN AWARD}

1. A Reminder List of all eligible motion pictures shall be made available along with a nominations ballot to all members of the Designers Branch, who shall vote in the order of their preference for not more than five motion pictures.

2. The five motion pictures receiving the highest number of votes shall become the nominations for final voting for the Production Design award.

3. Prior to the mailing of nominations ballots, a meeting of the Designers Branch shall be held to rule on the eligibility of all productions for Awards consideration. Eligibility for this award shall be limited to the production designer and set decorator primarily responsible for the design of the production and the execution of that concept. When the environment of a film is substantially composed of animation and digital artistry, the designer most responsible for that achievement also may be considered. In the case of fully animated feature films, the production designer alone shall be considered for that film.

4. The Designers Branch shall have the discretion to give more weight to design than to execution. Any submission requesting award eligibility for more than one production designer, more than one set decorator, or a digital artist, exhibiting extraordinary circumstances, must be accompanied by a letter of justification submitted by the producer and the production designer to the Academy no later than 5 p.m. PT on Friday, December 1, 2017. These circumstances will be reviewed at a special meeting of the Designers Branch; however, in no case will more than one additional award be 
considered. An art director may be considered eligible for the Production Design award only when a production designer is absent from the credits.

5. Except as indicated above, recognition in the form of the Academy statuette shall be given for the production design and for the set decoration of the motion picture receiving the Production Design award.

6. Final voting for the Production Design award shall be restricted to active and life Academy members.

\section{RULE EIGHTEEN SPECIAL RULES FOR THE SCIENTIFIC AND TECHNICAL AWARDS}

1. Academy Awards for scientific and technical achievement shall be made by the Board of Governors upon recommendation of the Scientific and Technical Awards Committee. Awards may be given for devices, methods, formulas, discoveries or inventions of special and outstanding value to the motion picture arts and sciences. No awards may be given posthumously.

2. The Academy President shall annually appoint outstanding representatives of the motion picture and technical fields to serve on the Scientific and Technical Awards Committee. The committee will be dissolved upon the completion of its annual term.

3. Awards for scientific and technical achievement may be granted in any of the following three classifications:

\section{ACADEMY AWARD OF MERIT \\ (Academy Statuette)}

For basic achievements that have a definite influence upon the advancement of the motion picture arts and sciences.

\section{SCIENTIFIC AND ENGINEERING AWARD}

(Academy Plaque)

For those achievements that exhibit a high level of engineering and are important to the progress of the motion picture arts and sciences.

\section{TECHNICAL ACHIEVEMENT AWARD (Academy Certificate)}

For those accomplishments that contribute to the progress of the motion picture arts and sciences.

4. The committee shall familiarize itself with all motion picture scientific and technical achievements of the current Awards year. To assist the committee, letters shall be sent to individuals and organizations engaged in scientific and technical developments for motion pictures, requesting that they submit any information they may have regarding achievements that may have been developed in their own or in any other organizations.

5. A list of all achievements being considered shall be widely publicized to permit anyone with claims of prior art or with devices similar to those under consideration to bring them to the attention of the committee.

6. The committee shall then conduct a series of meetings and examinations and, when feasible, shall arrange for such demonstrations as are necessary to evaluate the achievements properly and make recommendations for action by the Board of Governors. 
7. In evaluating the submitted achievements, the committee shall strive to seek out other items similar to those being considered for awards. If such items are discovered, they may be considered on an equal basis.

8. Where achievements are covered by patent(s), copies of the patent(s) shall be made available to the committee. If a patent is pending, the date of filing, name(s) of author(s), and application number must be submitted.

9. Full claim for originality and development of each achievement must be established to the satisfaction of the committee. If any controversy should arise as to the origin or authorship of an achievement, the committee may request that the Academy Board of Governors postpone action until proper credit is established.

10. The committee may appoint advisory groups for each technical classification in which there are achievements to be considered. The chairperson of each advisory group shall be one of the members of the advisory group and shall conduct its meetings and discussions.

11. Each advisory group shall consider all achievements in its field. The advisory groups shall evaluate those achievements and forward their conclusions to the Scientific and Technical Awards Committee in the form of a written report prepared by the respective advisory group chairpersons.

12. All voting by the Scientific and Technical Awards Committee shall be done by secret ballot. Committee members may voluntarily abstain from voting on any item. All decisions as to award recommendations and classifications shall require a two-thirds majority vote of those present and voting. Members of the committee having a personal connection with any achievement shall not be present during discussion of that achievement except by invitation of the chairperson. Members of the committee who do not have a personal connection with the achievement but who are affiliated with the organization responsible for the achievement may be present at the discussion and voting at the discretion of the chairperson, but may not vote on the achievement.

13. The committee shall carefully evaluate all information regarding actual authorship of each item being considered for an award and shall, at its sole discretion, identify the individual(s) and/or organization(s) to be recognized. The committee shall recommend to the Academy Board of Governors the person(s) and/or organization(s) to whom an award shall be made, the type of award and the text thereof.

14. In recommending awards, the committee will judge to the best of its ability the scientific and technical merits of the achievements, but does not warrant that the person or persons named are responsible for the origin or development of the achievement named in the award.

15. It shall be within the discretion of the committee to recommend no awards be given if, in its judgment, there have been no achievements worthy of recognition. It shall also be within the discretion of the committee, but only on its own motion, to review any Academy Award conferred for scientific and technical achievement to determine subsequent to the granting of such award whether the classification of such achievement should be elevated by reason of its contribution to the motion picture arts and sciences, and to recommend elevation in classification to the Academy Board of Governors.

16. Such other rules as may be considered necessary for the proper conduct of these awards shall be adopted by the Scientific and Technical Awards Committee, subject to the approval of the Academy Board of Governors.

\section{RULE NINETEEN \\ SPECIAL RULES FOR THE SHORT FILM AWARDS}




\section{DEFINITIONS}

A. A short film is defined as an original motion picture that has a running time of 40 minutes or less, including all credits.

B. This excludes from consideration such works as:

1. previews and advertising films

2. sequences from feature-length films, such as credit sequences

3. unaired episodes of established TV series

4. unsold TV series pilots

\section{CATEGORIES}

An award shall be given for the best achievement in each of two categories.

\section{A. Animated Short Film}

An animated film is defined as a motion picture in which movement and characters' performances are created using a frame-by-frame technique, and usually falls into one of the two general fields of animation: narrative or abstract. Some of the techniques of animating films include but are not limited to hand-drawn animation, computer animation, stop-motion, clay animation, pixilation, cutout animation, pinscreen, camera multiple pass imagery, kaleidoscopic effects created frame-by-frame, and drawing on the film frame itself. Motion capture and real-time puppetry are not by themselves animation techniques. An animated short film has a running time of 40 minutes or less. An animated feature film has a running time of more than $\mathbf{4 0}$ minutes. In an animated film, animation must figure in no less than 75 percent of the picture's running time. In addition, a narrative animated film must have a significant number of the major characters animated. If the picture is created in a cinematic style that could be mistaken for live action, the filmmaker(s) must also submit information supporting how and why the picture is substantially a work of animation rather than live action. Documentary short subjects that are animated may be submitted in either the Animated Short Film category or the Documentary Short Subject category, but not both.

\section{B. Live Action Short Film}

A live action film uses imagery created primarily through practical photographic techniques used to capture physical actors, props, sets, and locations. Documentary short subjects will not be accepted in the live action category. If the picture is created in the cinematic style of a documentary, the filmmaker(s) must also submit information supporting how and why the picture is substantially a work of fiction rather than a documentary.

\section{ELIGIBILITY}

A. To be eligible for award consideration for the 90th Awards year, a short film must fulfill one of the following qualifying criteria between October 1, 2016, and September 30, 2017. This qualification must take place within two years of the film's completion date:

1. The picture must have been publicly exhibited for paid admission in a commercial motion picture theater in Los Angeles County for a run of at least seven consecutive days with at least one screening a day prior to public exhibition or distribution by any nontheatrical means. The picture also must appear in the theater listings along with the appropriate dates and screening time(s).

All eligible motion pictures must be publicly exhibited by means of $35 \mathrm{~mm}$ or $70 \mathrm{~mm}$ film, or in a 24 or 48-frame progressive scan Digital Cinema format with a minimum projector resolution of 2048 by 1080 pixels, source image format conforming to ST 428-1:2006 D-Cinema Distribution Master 
- Image Characteristics; image compression (if used) conforming to ISO/IEC 15444-1 (JPEG 2000); and image and sound file formats suitable for exhibition in commercial Digital Cinema sites.

The audio in a Digital Cinema Package (DCP) is typically 5.1 or 7.1 channels of discrete audio. The minimum for a non-mono configuration of the audio shall be three channels as Left, Center, Right (a Left/Right configuration is not acceptable in a theatrical environment).

The audio data shall be formatted in conformance with ST 428-2:2006 D-Cinema Distribution Master - Audio Characteristics and ST 428-3:2006 D-Cinema Distribution Master - Audio Channel Mapping and Channel Labeling.

\section{Student films cannot qualify with a theatrical release.}

OR

2. The film must have won a qualifying award at a competitive film festival, as specified in the Short Film Qualifying Festival List, regardless of any prior public exhibition or distribution by nontheatrical means. Proof of the award must be submitted with the entry. The Short Film Qualifying Festival List is available at www.oscars.org or may be obtained from the Academy.

OR

3. The film must have won a Gold, Silver or Bronze Medal award in the Academy's 2017 Student Academy Awards competition in the Animation, Narrative, Alternative or Foreign Film category.

All films must be submitted in a standard theatrical exhibition aspect ratio, in formats currently accepted by the Academy (see Paragraph III.A.1 above), no matter which other formats may have been used during their theatrical run or festival screening. Producers may provide screenings of films in specialized formats for Academy members, but attendance at such screenings is not required for voting purposes.

B. A short film qualifying under Paragraph III.A.1 above may not be exhibited publicly or distributed anywhere in any nontheatrical form until after its Los Angeles theatrical release. Nontheatrical public exhibition or distribution includes but is not limited to:

- Broadcast and cable television

- PPV/VOD

- DVD distribution

- Internet transmission

Excerpts of the film totaling no more than ten percent of its running time are exempted from this rule.

Films qualifying under Paragraph III.A.2 or III.A.3 above are exempted from this rule.

\section{SUBMISSION}

A. Short films must be submitted to the Academy on $35 \mathrm{~mm}$ or $70 \mathrm{~mm}$ film, or as a DCP formatted according to the digital qualification standards described in Paragraph III.A.1 above, along with the digital content delivery of the film. Encrypted films will not be accepted. Formats requiring special technical presentation that meet the technical specifications above will be given consideration if made available for Academy voting screenings in Los Angeles County.

B. The print or DCP of the short film submitted for Academy Awards consideration must be identical in content and length to the print or DCP that qualified. 
C. Dialogue or narration must be substantially in English or the film must have English-language subtitles.

D. Prints or DCPs should be marked "Short Film Entry" and shipped prepaid to the Academy of Motion Picture Arts and Sciences, 8949 Wilshire Blvd., Beverly Hills, CA 90211. Prints or DCPs submitted will be retained by the Academy throughout the voting process.

E. The deadline for receiving all required entry materials, including the film print or DCP and the digital content delivery of the film, is $\mathbf{5}$ p.m. PT on Monday, October 2, 2017. Foreign entries also must comply with this rule.

F. If a short film advances to the second round of voting, an additional film print or DCP must be received by the Academy by 5 p.m. PT five business days after the shortlist is announced. If a DCP was submitted, a second DCP must be sent to the Academy. If a film print was submitted, a second print of the picture must be sent to the Academy. In addition, five Region 0/NTSC standard definition DVDs of the shortlisted film must be submitted for Academy records. Shortlisted films must have the necessary clearances for commercial theatrical exhibition. Festival clearances are not sufficient.

G. The Academy will retain for its archives one film print or DCP and DVDs of every short film receiving a nomination for final balloting. The Academy will have the right, but not the obligation, to create a preservation copy of the picture at its own expense. All pictures that are not nominated will be returned at Academy expense. By submitting a film, the filmmaker agrees that the Academy has the right to make copies and distribute them for voting purposes only.

$\mathrm{H}$. The recipient of the Oscar will be the individual most directly responsible for the concept and the creative execution of the film. In the event that more than one individual has been directly and importantly involved in creative decisions, a second statuette may be awarded. However, no more than two awards will be given to a winning production. Companies or organized groups shall not receive nominations or awards.

I. No short film may be submitted more than once for Academy Awards consideration. A short film must be submitted in the same Awards year in which it qualifies.

\section{VOTING}

A. Excellence of the entries shall be judged on the basis of originality, entertainment and production quality without regard to cost of production or subject matter.

B. A reviewing process will take place, in which volunteer active and life members of the Short Films and Feature Animation Branch will view all motion pictures entered and mark all entries 10, 9, 8, 7, or 6 with the guidelines of 10 (excellent), 8 (good), 7 (fair) or 6 (poor). In each category not more than ten pictures receiving the highest average numerical scores above 7.5 shall be considered further. In the event that fewer than six pictures receive average numerical scores above 7.5 , those with the next highest average numerical scores shall be included until six pictures are selected.

C. To determine nominations, all entries selected during the reviewing process shall be screened by the Branch Nominating Committee consisting of all active and life members of the Short Films and Feature Animation Branch. A member must see all shortlisted films for the ballot to be counted. Those members of the branch who participated in the reviewing process and who viewed all of the selected pictures, in either or both categories, will receive ballots. The running order of the films in each category shall be organized by aspect ratio. Members shall vote in the order of their preference for not more than five pictures in each category. The five pictures receiving the highest number of votes in each category shall become the nominations for final voting for the Short Film awards. 
D. Final voting for the Animated Short Film and Live Action Short Film awards shall be restricted to active and life members of the Academy who have viewed all of the nominated short films. Academy members may vote for only one film in each of the two categories.

\section{ADVERTISING AND PUBLICITY RESTRICTIONS}

Only short films that receive nominations or Academy Awards may refer to their Academy endorsements in advertising and publicity materials. A film that is selected for the shortlist may not identify itself as an "Academy Award finalist," "Academy Award shortlist film" or the like except when it appears in a program consisting entirely of such films.

\section{RULE TWENTY SPECIAL RULES FOR THE SOUND EDITING AWARD}

1. A Reminder List of all eligible productions shall be made available along with a nominations ballot to all members of the Sound Branch who shall vote in the order of their preference for not more than five productions.

2. The five productions receiving the highest number of votes shall become the nominations for final voting for the Sound Editing award.

3. Eligibility for this award shall be limited to the sound editing supervisor(s) - not to exceed two directly involved in and primarily responsible for the planning, creation, direction, and execution of the sound design and editing for each achievement. The supervisor(s) must be the primary creative decision maker and principal interpreter of the director's vision to the sound editing team. The supervisor(s) must approve the sound effects and their specific placement in the film, coordinate the creation of newly designed sound and Foley effects, and coordinate the editing of dialogue and ADR. The supervisor(s) must oversee the recording of the pre-dubs and be present at the final mix. In the event the above responsibilities are divided, both co-supervisors must adhere to the above criteria.

4. In cases where more than one supervisor on a film claims eligibility for the Sound Editing award, each individual must submit a letter to the Sound Branch Executive Committee describing their contribution to the film in detail. Letters must be received by the Academy no later than $\mathbf{5}$ p.m. PT on Friday, December 1, 2017.

5. Nomination eligibility of the supervisor(s) responsible for the achievement shall be determined by the Sound Branch Executive Committee.

6. Final voting for the Sound Editing award shall be restricted to active and life Academy members.

\section{RULE TWENTY-ONE SPECIAL RULES FOR THE SOUND MIXING AWARD}

1. A Reminder List of all eligible motion pictures shall be made available along with a nominations ballot to all members of the Sound Branch, who shall vote in the order of their preference for not more than five pictures.

2. The five pictures receiving the highest number of votes shall become the nominations for final voting for the Sound Mixing award. 
3. The talents of the rerecording mixer(s) on a panel (not to exceed three) and the production mixer will be judged as contributing equally to a soundtrack achievement. On the Official Screen Credits form supplied to the Academy, no more than three eligible co-rerecording mixers who have contributed substantially to the final mix, and no more than one production mixer, shall be designated for Academy Awards purposes.

4. In cases where more than one production mixer on a film claims eligibility for the Sound Mixing award, each individual must submit a letter to the Sound Branch Executive Committee describing their contribution to the film in detail. Letters must be received by the Academy no later than $\mathbf{5}$ p.m. PT on Friday, December 1, 2017.

5. In the event of a credits dispute, the nomination eligibility for the Sound Mixing award shall be determined by the Sound Branch Executive Committee.

6. Following a review of the Official Screen Credits, determination of nomination eligibility shall be the responsibility of the Academy.

7. The Theater Sound Inspection Committee shall inspect and approve the projection sound systems of the Academy's theaters prior to the annual screening of nominated achievements. No changes may be made in the sound systems after final approval by the committee. Any composite release print that plays on the normal projection sound system of the Academy's theaters requires no special approval of the committee. Any production that deviates from the normal sound system, or requires modification of the system, must be approved by a majority of the committee before the final check of the system. Notification of such deviation or modification requirements must be submitted to the Academy at least three weeks in advance of the annual screenings of the nominated achievements.

8. Before screening motion pictures nominated for the Sound Mixing award, representatives of the pictures to be shown may run a maximum of $\mathbf{2 0}$ contiguous minutes of their pictures to audition them. At the actual screenings, pictures will be run at the Academy Standard sound level.

9. Final voting for the Sound Mixing award shall be restricted to active and life Academy members.

\section{RULE TWENTY-TWO SPECIAL RULES FOR THE VISUAL EFFECTS AWARD}

1. The Academy President shall appoint a chairperson who will form an Executive/Steering committee from active and life members from the Visual Effects Branch.

2. The Visual Effects Branch Executive Committee shall review a reminder list of all eligible motion pictures and through a series of meetings, shall cast secret ballots to select a maximum of 20 films for further consideration. Achievements shall be judged within the parameters defined by the Executive Committee and on the basis of:

a. consideration of the contribution the visual effects make to the overall production and

b. the artistry, skill and fidelity with which the visual illusions are achieved.

3. The Executive Committee will request that producers provide opportunities to view their films through advance screenings or screeners. This is especially encouraged when a film will be released after the selection meeting to determine the ten motion pictures that will be considered for nomination. If, and only if, the film is not available by two weeks prior to the selection meeting, excerpts may be submitted. 
4. The producers of the ten motion pictures that will be considered for nomination (or their designees) shall be requested to provide the committee with the following:

a. Written descriptions of and visual material illustrating the procedures used to create the effects.

b. Excerpts from the digital release DCP of the motion picture - not to exceed ten minutes in total running time - showing the effects described. This composition playlist must reference only the theatrical release DCP media essence files and must be identified with "VFX_Bakeoff" for presentation purposes. Editorial and sound blends between excerpts will not be permitted, with the exception of an audio-only crossfade not to exceed $1 / 4$ second across cuts for the purpose of minimizing pops and clicks. A separate soundtrack may be provided for that purpose, which must otherwise be identical to the DCP soundtrack as cut. If the total composition playlist does not meet these requirements, the producers shall be notified and given an opportunity to make corrections within the deadline period, otherwise it will not be exhibited. For archival purposes, an archival key (aka DKDM) for the composition playlist also must be provided.

Producers wishing to submit a film excerpt reel instead may do so, provided the motion picture was originally released in that format. In this case, a duplicate excerpt reel from the composite release print must be provided for archiving.

The producers shall provide the Academy the right to use the excerpts for any voting purposes, and for any nonprofit purposes of the Academy Museum, the Academy Foundation or Academy websites.

c. A multimedia file version of the composition playlist or excerpt reel for use in the production of the Academy Awards telecast.

d. The names and titles of the primary individuals - not to exceed four in number - directly involved with, and principally responsible for, the visual effects achieved and a description of their contributions. Additional names will not be considered. The Visual Effects award is a craft award. Producers, coordinators and other executives are not eligible for this award unless they are also craftspeople with primary creative responsibility for the achievement.

5. Visual effects, as an achievement or a craft, shall be determined by the Visual Effects Branch Executive Committee. Eligibility of the contributor(s) to the achievement, for nomination purposes, shall also be determined by the Executive Committee.

6. Qualified active members of the Visual Effects Branch will be eligible to serve as the Visual Effects Award Nominating Committee and shall attend a meeting to view the excerpts and vote upon the achievements. Written descriptions of the effects shall be made available to the Nominating Committee prior to the meeting.

7. The producers (or their designees) may attend the meeting of the Nominating Committee, however, only the potential nominees will be allowed to address the Nominating Committee.

8. Following the running of the excerpts and discussion relative to the achievements, voting shall be conducted as follows:

a. A ballot shall be cast by all members of the Visual Effects Award Nominating Committee present on the ten productions under consideration.

b. Five productions shall be selected using reweighted range voting to become the nominations for final voting for the Visual Effects award.

c. Final voting for the Visual Effects award shall be restricted to active and life Academy members. 
9. Composition playlists and excerpt reels shall become the property of the Academy and placed in the Academy Film Archive, with the proviso that the Academy will not use the excerpts for commercial gain.

10. Such other rules or procedures necessary for the proper conduct of this award shall be adopted by the Visual Effects Branch Executive Committee, subject to the approval of the Academy Board of Governors.

\section{RULE TWENTY-THREE \\ SPECIAL RULES FOR THE WRITING AWARDS}

1. An award shall be given for the best achievement in each of two categories:

\section{Adapted Screenplay}

Original Screenplay

2. A Reminder List of all eligible screenplays in each category shall be made available along with nominations ballots to all members of the Writers Branch, who shall vote in the order of their preference for not more than five screenplays in each category.

3. The five screenplays in each category receiving the highest number of votes shall become the nominations for final voting for the Writing awards.

4. The Writers Branch Executive Committee shall resolve all questions of eligibility and rules.

5. Final voting for the Writing awards shall be restricted to active and life Academy members.

\section{RULE TWENTY-FOUR RULES FOR THE GOVERNORS AWARDS}

\section{DEFINITIONS}

The Governors Awards include the Irving G. Thalberg Memorial Award, the Jean Hersholt Humanitarian Award and the Honorary Award. They are determined and bestowed by the Board of Governors.

\section{NOMINATING AND VOTING PROCEDURES}

A. Nominations for the Governors Awards shall be made at an annually designated meeting of the Board of Governors. Nominations for all three awards shall be conducted as a single procedure in which a nominee is named along with the award for which he or she is proposed.

B. When the nominations are closed, voting shall be conducted by secret ballot. The governors shall indicate their preference for a Governors Award by selecting one candidate from among the names listed. The candidate who receives a majority of the votes shall then stand for further consideration. If a tie occurs, a run-off vote between the tied candidates shall take place until a preferred candidate is determined.

C. If after the first round no candidate receives a majority of the votes, the two candidates with the lowest number of votes shall be eliminated and the remaining candidates shall stand for a second round of voting. If after the second round of voting no candidate receives a majority of the votes, the 
one candidate receiving the lowest number of votes shall be eliminated and the remaining candidates shall be voted upon. If, during any round of voting in which no candidate receives a majority, there are two or more candidates tied with the lowest number of votes, and if they do not comprise more than half of the entire field of candidates still under consideration, then all of those candidates who are tied with the lowest number of votes shall be eliminated. If those tied with the lowest number of votes comprise more than half of the remaining field, then the Governors shall vote by ranking those who are tied in order of preference; the resulting top vote-getter shall remain on the ballot and the others shall be eliminated. This process of elimination shall continue until a candidate with a majority is determined.

D. A second and third Governors Award may also be presented, following the same nominating and voting procedures as described above. A fourth Governors Award may be presented only if a majority of governors present first vote that a fourth award should be given. If the vote to give a fourth Governors Award is passed, the award will be decided using the same nominating and voting procedures as described.

\section{LIMITATIONS}

A. No more than four Governors Awards may be presented in a given Awards year.

B. No more than one Jean Hersholt Humanitarian Award and one Irving G. Thalberg Memorial Award may be presented in a given Awards year. There is no such restriction on the Honorary Award.

C. No proxies shall be permitted in balloting for any Governors Award.

D. No Governors Award shall be voted posthumously.

E. No sitting member of the Board of Governors shall be eligible to receive a Governors Award.

F. No individual shall be eligible to receive any particular Governors Award more than once.

\section{RULE TWENTY-FIVE RULES FOR THE SPECIAL ACHIEVEMENT AWARD}

1. This award shall be given for an achievement which makes an exceptional contribution to the motion picture for which it was created, but for which there is no annual award category. Such award shall only be conferred, however, for achievements in productions that also qualify under Rules Two and Three.

2. Nominations for the Special Achievement Award shall be made at a special meeting of the Board of Governors.

3. Following completion of the nominations for this award, a secret ballot shall be taken on which the governors vote for the nominee of their preference. The nominee receiving the highest numerical score shall be considered further in a second secret ballot to determine if this award shall be given. If the achievement receives a vote of two-thirds of the governors present, the person(s) named as being responsible for the achievement shall receive the Special Achievement Award.

4. No proxies shall be permitted in balloting for the Special Achievement Award.

5. Such other rules or modifications as may be necessary for the proper conduct of this award shall be adopted by the Board of Governors. 


\section{RULE TWENTY-SIX \\ RULES FOR THE \\ SCIENTIFIC AND TECHNICAL SPECIAL AWARDS}

1. The Scientific and Technical Special Awards may include:

a. GORDON E. SAWYER AWARD (Statuette). This award shall be given to an individual whose technological contributions have made an extraordinary and lasting impact on the motion picture industry.

b. AWARD OF COMMENDATION (Special Plaque). This award shall be given in recognition of special technical achievements in the motion picture arts and sciences.

2. The Service Awards may include:

a. JOHN A. BONNER AWARD (Medallion). This award shall be given to an individual in recognition of extraordinary service to the motion picture industry.

3. A Special Awards Search Committee will identify potential candidates for the Gordon E. Sawyer Award and the John A. Bonner Award. This committee will be composed of the Chair and Vice Chair of the Scientific and Technical Awards Committee, the Chair of the Awards and Events committee, three other members of the Awards and Events committee, and five Academy members selected by the President.

a. Any candidate must be endorsed by two members of the Special Awards Search Committee to be considered.

b. The Special Awards Search Committee will form surrogate groups to investigate the candidates' careers and contributions.

c. Each surrogate group will produce a report on each candidate which will include a minimum of three letters of recommendation from active Academy members.

4. The Scientific and Technical Awards Main Committee may propose candidates for the Award of Commendation and forward their recommendations to the Awards and Events Committee for consideration.

5. No sitting member of the Board of Governors shall be eligible to receive the Gordon E. Sawyer Award or the John A. Bonner Award, and shall remain ineligible for a period of three years after their term has ended. Governors are eligible for the Award of Commendation.

6. No current employee of the Academy of Motion Picture Arts and Sciences shall be eligible for the Gordon E. Sawyer Award or the John A. Bonner Award, and shall remain ineligible for a period of three years after their employment has ended. Employees are eligible for the Award of Commendation.

7. The names of the proposed award recipients, along with the corresponding summary reports and letters of recommendation, will be brought before the Awards and Events Committee. A vote of twothirds of the committee members is necessary to approve and endorse each proposal to be presented to the Board of Governors.

8. The names of the award recipients approved by the Awards and Events Committee, along with the corresponding summary reports and letters of recommendation, will then be brought before the Board of Governors for consideration. A vote of two-thirds of the Board of Governors is necessary to bestow any of these awards. 
9. No more than one Gordon E. Sawyer Award and one John A. Bonner Award may be presented in a given Awards year. There is no such restriction on the Award of Commendation.

10. All voting will be done by secret ballot. No proxies shall be permitted in balloting for any of these Special Awards. No Special Awards shall be voted posthumously. 